\title{
Effect of Grasping Computer Mouse on Median Nerve Conduction Velocity in Computer Users
}

\author{
RAGHDA A.M. IBRAHIM, M.Sc.*; HAYTHAM M. EL-HAFEZ, Ph.D.*; RANIA N. KARKOSHA, Ph.D.* and \\ SAMY HASSANEN, M.D.** \\ The Department of Basic Sciences, Faculty of Physical Therapy, Cairo University* and The Department of Neurosurgery, \\ Faculty of Medicine, Zagazig University**
}

\begin{abstract}
Background: Computer users with a long daily duration of computer use experienced musculoskeletal and neural symptoms.

Aim of Study: To examine the possible effect of grasping the computer mouse on median nerve conduction velocity in computer users.

Material and Methods: Forty adult computer users of both genders participated in this study. Their age ranged from 20 to 45 years old and they were using computer as a basic agent in their work. The computer users assigned in to two groups: Group A: Twenty participants using computer from 2 to 4 years and Group B: Twenty participants using computer from 5 to 7 year. The Median nerve conduction velocity of both dominant and non-dominant hands of both groups was measured.
\end{abstract}

Results: There is a great effect of using computer mouse on median nerve conduction velocity in computer users.

Conclusion: Using the computer mouse for a long time affect the median nerve conduction velocity in computer users.

Key Words: Computer mouse - Median nerve - Conduction velocity - Computer users.

\section{Introduction}

THE Information Technology (IT) revolution has embraced everyone in its stride. People are on the verge of becoming computer savvy or already are computer literate. As a coin has two sides, the IT revolution has proved to be simultaneously a boon and a bane. It is a boon as it facilitates data interpretation, faster communication, speeds work completion and much more; on the other hand, it is a bane for those involved in providing the IT sector with its true face value. Intensive computer work can increase the risk of developing musculoskeletal

Correspondence to: Dr. Raghda A.M. Ibrahim, E-Mail: rodynodv88@gmail.com symptoms and disorders in the upper extremities. [1-4].

Computer users with a long daily duration of computer use experienced more musculoskeletal symptoms than those with a short duration of computer use. Computer work in general seemed characterized by repetitive movements, which may be a risk factor for musculoskeletal symptoms [2].

The repetitive computer use such as typing the keyboard and drig-drag the mouse overloads neck, shoulder, arm and hand muscles and joints. As they continue to be overworked, cumulative trauma happens. The muscles in the forearm that control the movement of fingers may become irritated and soft tissues become inflamed and swollen. The irritated muscles, swollen tendons and soft tissues can press on the nearby nerves and cause ischemic neurophysiological changes: A progressive reduction in nerve conduction appears, resulting in a transient increase in the sensation, numbness, tingling and then weakness and in advanced cases the outcome is a loss of strength and hand wrist pain such as Carpal Tunnel Syndrome (CTS) $[5,6]$ The risk factors associated with the conventional mouse are contact pressure on the palm, a pronated forearm posture, repeated or sustained pinching, wrist extension, or wrist deviation [7]

Chronic peripheral nerve injury is usually the result of longstanding compression, repeated traction at entrapment sites, or traumatically altered regional anatomy. The result is focal axonal disruption and/or focal segmental demyelination [8] Determining whether there is a link between entrapment neuropathies and the ever increasing use of computers in the workplace and at home [7] The median nerve enters the hand above the bones 
of the wrist by passing beneath the transverse carpal ligament. Compression of the median nerve at the wrist, or CTS, is the most common compressive neuropathy [8].

In recent years, with the expanding use of computers, it has been a matter of concern if computer use could be a risk factor for the development of CTS. In a cross-section prospective study AlHashem and Khalid [9] assessed the effect of longterm use of computer mouse devices on the median nerve in healthy frequent computer users. They reported that over one third (35\%) of asymptomatic participants and half of the participants who reported right hand discomfort after computer use, but did not meet clinical criteria for CTS (positive Phalen's and Tinel's signs), showed electrophysiological evidence suggestive of right median nerve entrapment neuropathy at the wrist. They suggested that frequent computer users have a tendency to median nerve entrapment neuropathy at the wrist.

A study by Murata et al., [10] found reduced sensory nerve conduction velocity in the median nerve across the carpal tunnel among computer operators compared with healthy controls, indicating that a subclinical CTS was associated with computer use. Both ulnar deviation and extension of the wrist increase CTP [11,12] . Accordingly, the current study was conducted to examine the effect of grasping computer mouse on median nerve conduction velocity in computer users.

\section{Material and Methods}

The current study was conducted at the Physical Therapy Department, Al-Salhia Al-Gadeda AlMarkazy Hospital, Ministry of Health, El-Sharkia Governorate, Egypt. This has been done at the period from May 2015 to January 2018 to examine the effect of grasping computer mouse on median nerve conduction velocity in computer users.

Design of the study: Cross section study (snapshot) design was used to examine the effect of grasping computer mouse on median nerve conduction velocity in computer users.

Subjects: Forty adult computer users of both genders participated in this study. Their age ranged from 20 to 45 years old and they were using computer as a basic agent in their work.

Computer users were be assigned in two groups: Group A: Included twenty " 20 " participants using computer from 2 to 4 years. Group B: Included twenty"20" participants using computer from 5 to 7 years. Median nerve in the dominant hand was measured and the non-dominant hand used as a control.

Subjects who participated in this study had the following criteria:

- All participants were using computer for at least two years.

- All participants were using computer for at least 2 hours per day.

- Their age ranged from 20 to 45 years old.

\section{Exclusion criteria were:}

- Previous or current illness or trauma that affected one or both upper limbs.

- Repetitive motions of the wrist other than that due to computer use.

- Metabolic diseases that may be associated with entrapment neuropathy such as diabetes mellitus, thyroid diseases, and autoimmune diseases.

- Pregnant women.

- Participants with congenital hand deformities.

- History of hand surgery.

\section{Instrumentation:}

Electromyography (EMG) apparatus: BIOPAC System was be used to make the Nerve Conduction Study (NCS) of the Median nerve.

\section{Procedure:}

Both right and left median nerves conduction velocity of both Groups A and B were measured.

\section{I- Motor nerve of median nerve:}

This performed by electrical stimulation of a peripheral nerve and recording from a muscle supplied by this nerve. So, the recording electrode ( ve) was placed at the fleshy part of the abductor policis brevis and the reference electrode (+ve) at the tendon of the abductor policis brevis (at the tip of the thumb) and the ground electrode between the recording and the reference electrodes. Then the stimulation electrode was placed at the volar aspect of the wrist at its middle part (at the carpal tunnel), then the intensity was increased and press inter so make the stimulation and the action potential appeared. This called distal site of stimulation.

To measure the (NCV) must make proximal site of stimulation, in this procedure insert the stimulating electrode at medial side of volar aspect of elbow and the recording in the same place(at the fleshy part of the abductor policis brevis). So, measure distal latency (time from stimulation site to recording site in mille second at wrist) and 
measure the proximal latency (time from stimulation site to recording site in mille second at elbow) and take the difference between them. Also, measure the amplitude of the action potential and measure the distance from stimulation site to recording site at wrist and at elbow and take difference between them in mille meter. So, now we had latency (time) and distance, so, got the velocity $\mathrm{NCV}=$ distance/latency.

\section{II- Sensory nerve of median nerve:}

Sensory NCS are performed by electrical stimulation of a peripheral nerve and recording from a purely sensory portion of the nerve, such as on a finger. Site of stimulation the same as motor nerve at the volar aspect of the wrist at its middle part (at the carpal tunnel) but the recording on the second digit. (The recording electrode on the proximal phalanx and the reference on the distal phalanx). So, measure the NCV of the sensory branch the same as motor branch.

\section{Statistical analysis:}

Descriptive analysis was used it includes: The mean (X): As an average describing the central tendency of observation. The Standard Deviation (SD): As a measure of the dispersion of the result around the mean. Inferential statistics was used as two way ANOVA to Identify the effect of years of using the computer mouse on median nerve conduction velocity in computer users. The level of significance will set less than 0.05 .

\section{Results}

\section{Results of Group A:}

\section{Motor and sensory latencies of the median nerve:}

Motor latency: The motor latency of the median nerve was measured at the wrist and elbow joints. The mean value at wrist was $3.01 \pm 0.26 \mathrm{~ms}$ of the right side and $2.87 \pm 0.42 \mathrm{~ms}$ of the left side. This showed non significance difference between both sides $(t=0.78$ and $p<0.22)$. The mean value at elbow was $6.94 \pm 0.56 \mathrm{~ms}$ of the right side and $6.55 \pm 0.55$ $\mathrm{ms}$ of the left side. This showed non significance difference between both sides $(t=1.39$ and $p<0.09)$.

Sensory latency: The sensory latency of the median nerve was measured at the wrist and elbow joints. The mean value at wrist was $2.24 \pm 0.28 \mathrm{~ms}$ of the right side and $2.37 \pm 0.37 \mathrm{~ms}$ of the left side. This showed non significance difference between both sides $(t=0.78$ and $p<0.22$ ). The mean value at elbow was $5.65 \pm 0.51 \mathrm{~ms}$ of the right side and $5.3 \pm 0.76 \mathrm{~ms}$ of the left side. This showed non significance difference between both sides $(t=1.07$ and $p<0.15$ ).
Motor and sensory amplitude of the median nerve:

Motor amplitude: The motor amplitude of the median nerve was measured at the wrist and elbow joints. The mean value at wrist was $9.58 \pm 3.07 \mathrm{mV}$ of the right side and $10.71 \pm 4.82 \mathrm{mV}$ of the left side. This showed non significance difference between both sides $(t=-0.55$ and $p<0.29)$. The mean value at elbow was $6.28 \pm 2.61 \mathrm{mV}$ of the right side and $9.13 \pm 4.4 \mathrm{mV}$ of the left side. This showed non significance difference between both sides $(t=-1.56$ and $p<0.06$ ).

Sensory amplitude: The sensory amplitude of the median nerve was measured at the wrist and elbow joints. The mean value at wrist was $50.85 \pm$ $17.23 \mathrm{mV}$ of the right side and $66.87 \pm 26.57 \mathrm{mV}$ of the left side. This showed non significance difference between both sides ( $t=-1.43$ and $p<0.08)$. The mean value at elbow was $35.17 \pm 11.92 \mathrm{mV}$ of the right side and $51.76 \pm 40.67 \mathrm{mV}$ of the left side. This showed non significance difference between both sides $(t=-1.10$ and $p<0.14)$.

\section{Nerve conduction velocity of the median nerve:}

Motor NCV: As shown in (Table 1) and Fig. (1) the motor NCV of the median nerve was measured at right and left wrist. The mean value of $\mathrm{NCV}$ at right wrist was $62.12 \pm 5.16 \mathrm{~m} / \mathrm{s}$ and $66.5 \pm$ $4.98 \mathrm{~m} / \mathrm{s}$ at the left wrist. This showed a significance difference between both sides $(t=-1.72$ and $p<0.05)$.

Table (1): Mean values of motor median nerve conduction velocity of Group A.

\begin{tabular}{llll}
\hline & \multicolumn{2}{c}{ RT } & LT \\
\hline & Mean & 62.12 & 66.5 \\
& SD & 5.16 & 4.98 \\
& SEM & 1.82 & 1.76 \\
& $t$-test & & -1.72 \\
& Prop. & 0.05 \\
& Sig. & Sig. \\
\hline SD & : Standard Deviation. & p-value : Probability. \\
SEM & : Standard Error of Mean. & Sig. & : Significance. \\
$t$-value & : Student's $t$-test value. & &
\end{tabular}

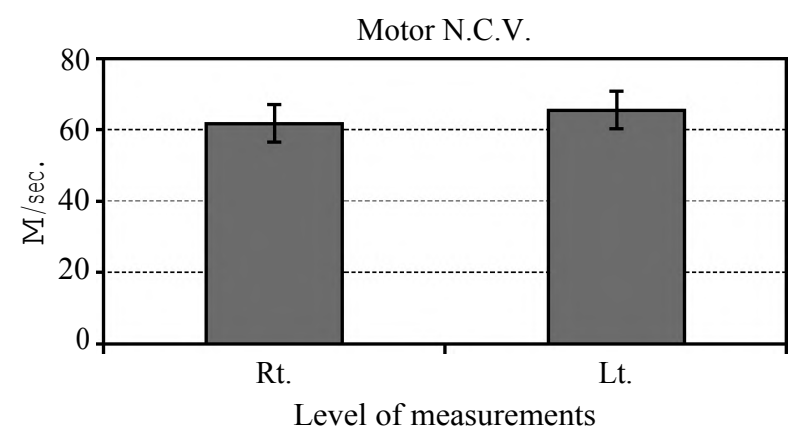

Fig. (1): Mean values of motor median nerve conduction velocity of Group A. 
Sensory NCV: As shown in (Table 2) and Fig. (2) the sensory NCV of the median nerve was measured at right and left wrist. The mean value of NCV at right wrist was $72 \pm 8.19 \mathrm{~m} / \mathrm{s}$ and $88.5 \pm$ $27.60 \mathrm{~m} / \mathrm{s}$ at the left wrist. This showed non significance difference between both sides $(t=1.62$ and $p<0.06$ ).

Table (2): Mean values of sensory median nerve conduction velocity of Group A.

\begin{tabular}{llll}
\hline & & RT & LT \\
\hline & Mean & 72 & 88.5 \\
& SD & 8.19 & 27.60 \\
& SEM & 2.89 & 9.76 \\
& $t$-test & -1.62 \\
& Prop. & 0.06 \\
& Sig. & Non-sig. \\
& SD & : Standard Deviation. & p-value : Probability. \\
SEM & : Standard Error of Mean. & Sig. & : Significance. \\
$t$-value & : Student's $t$-test value. & \multicolumn{2}{c}{}
\end{tabular}

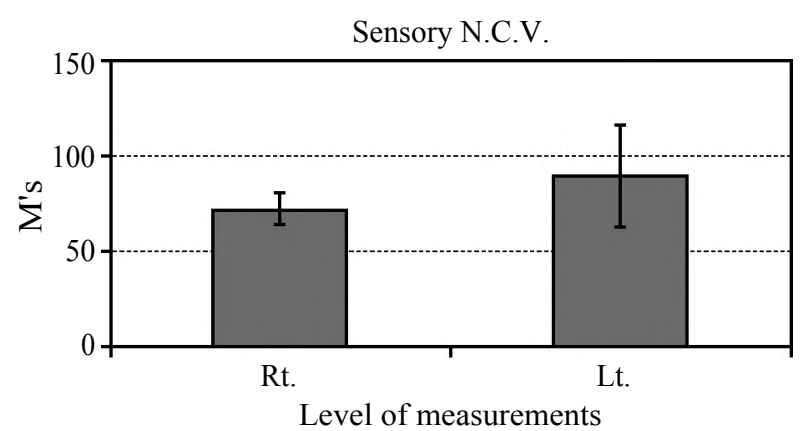

Fig. (2): Mean values of sensory median nerve conduction velocity of Group A.

Results of Group B:

Motor and sensory latencies of the median nerve:

Motor latency: As shown in (Table 3) and Fig. (3) the motor latency of the median nerve was measured at the wrist and elbow joints. The mean value at wrist was $2.83 \pm 0.33 \mathrm{~ms}$ of the right side and $3.11 \pm 0.98 \mathrm{~ms}$ of the left side. This showed non significance difference between both sides $(t=-0.75$ and $p<0.23$ ). The mean value at elbow was 6.86 $\pm 0.59 \mathrm{~ms}$ of the right side and $7.12 \pm 1.24 \mathrm{~ms}$ of the left side. This showed non significance difference between both sides $(t=-0.53$ and $p<0.29)$.

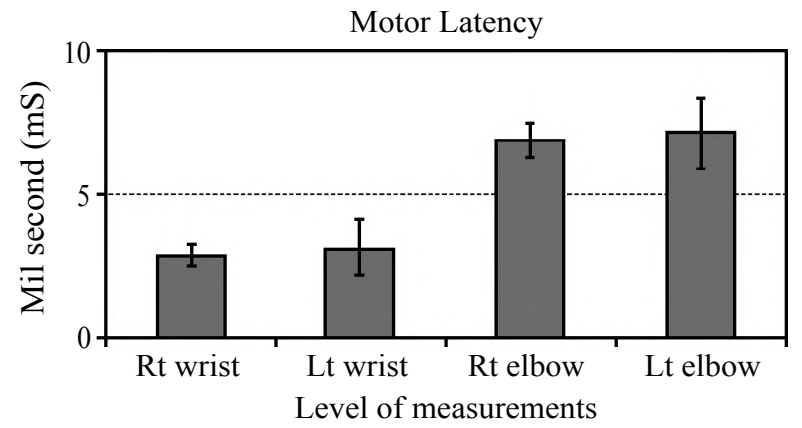

Fig. (3): Mean values of median nerve motor latency of Group B.
Table (3): The statistical analysis of median nerve motor latency of Group B.

\begin{tabular}{|c|c|c|c|c|}
\hline & \multicolumn{2}{|c|}{ Wrist } & \multicolumn{2}{|c|}{ Elbow } \\
\hline & $\mathrm{Rt}$ & $\mathrm{Lt}$ & Rt & $\mathrm{Lt}$ \\
\hline Mean & 2.83 & 3.11 & 6.86 & 7.12 \\
\hline SD & 0.33 & 0.98 & 0.59 & 1.24 \\
\hline SEM & 0.11 & 0.34 & 0.21 & 0.44 \\
\hline$t$-test & & -0.75 & & -0.53 \\
\hline Prop. & & 0.23 & & 0.29 \\
\hline \multirow[t]{2}{*}{ Sig. } & & Non-sig. & & Non-sig. \\
\hline & & & $\begin{array}{l}\text { Rt wrist vs } \\
\text { Rt Elbow }\end{array}$ & $\begin{array}{l}\text { Lt Wrist vs } \\
\text { Lt elbow }\end{array}$ \\
\hline$t$-test & & & -16.63 & -7.15 \\
\hline Prop. & & & 0.0001 & 0.0001 \\
\hline Sig. & & & HS & HS \\
\hline $\begin{array}{l}\text { SD } \\
\text { SEM } \\
t \text {-value }\end{array}$ & $\begin{array}{l}\text { Standard } \\
\text { Standard } \\
\text { Student's }\end{array}$ & $\begin{array}{l}\text { viation. } \\
\text { ror of Mean. } \\
\text { est value. }\end{array}$ & $\begin{array}{l}p \text {-value : } \mathrm{P} \\
\text { Sig. } \quad: \mathrm{S} \\
\mathrm{HS}\end{array}$ & $\begin{array}{l}\text { bility. } \\
\text { ficance. } \\
\text { Significance. }\end{array}$ \\
\hline
\end{tabular}

Sensory latency: As shown in (Table 4) and Fig. (4) the sensory latency of the median nerve was measured at the wrist and elbow joints. The mean value at wrist was $2.32 \pm 0.26 \mathrm{~ms}$ of the right side and $2.34 \pm 0.22 \mathrm{~ms}$ of the left side. This showed non significance difference between both sides ( $t=$ -0.16 and $p<0.43$ ). The mean value at elbow was $5.77 \pm 1.04 \mathrm{~ms}$ of the right side and $5.48 \pm 0.66 \mathrm{~ms}$ of the left side. This showed non significance difference between both sides ( $t=0.66$ and $p<0.25)$.

\section{Motor and sensory amplitude of the median nerve:}

Motor amplitude: The motor amplitude of the median nerve was measured at the wrist and elbow joints. The mean value at wrist was $11.45 \pm 2.42$ $\mathrm{mV}$ of the right side and $11.51 \pm 2.55 \mathrm{mV}$ of the left side. This showed non significance difference between both sides ( $t=0.05$ and $p<0.48$ ). The mean value at elbow was $8.96 \pm 3.36 \mathrm{mV}$ of the right side and $8.7 \pm 3.74 \mathrm{mV}$ of the left side. This showed non significance difference between both sides ( $t=$ 0.14 and $p<0.44$ ).

Sensory amplitude: The sensory amplitude of the median nerve was measured at the wrist and elbow joints. The mean value at wrist was $73.22 \pm$ $47.04 \mathrm{mV}$ of the right side and $79.13 \pm 37.73 \mathrm{mV}$ of the left side. This showed non significance difference between both sides ( $t=-0.27$ and $p<0.39$ ). The mean value at elbow was $27.81 \pm 12.75 \mathrm{mV}$ of the right side and $62.27 \pm 87.88 \mathrm{mV}$ of the left side. This showed non significance difference between both sides $(t=-1.09$ and $p<0.14)$.

Nerve conduction velocity of the median nerve:

Motor NCV: The median nerve was measured at right and left wrist. The mean value of $\mathrm{NCV}$ at 
right wrist was $61 \pm 5.34 \mathrm{~m} / \mathrm{s}$ and $61.25 \pm 5.49 \mathrm{~m} / \mathrm{s}$ at the left wrist. This showed Non-significance difference between both sides ( $t=0.09$ and $p<0.46$ ).

Sensory NCV: The sensory NCV of the median nerve was measured at right and left wrist. The mean value of NCV at right wrist was $77.62 \pm 33.08$ $\mathrm{m} / \mathrm{s}$ and $79.75 \pm 15.04 \mathrm{~m} / \mathrm{s}$ at the left wrist. This showed non significance difference between both sides $(t=0.16$ and $p<0.43)$.

Table (4): The statistical analysis of median nerve sensory latency of Group B.

\begin{tabular}{|c|c|c|c|c|}
\hline & \multicolumn{2}{|c|}{ Wrist } & \multicolumn{2}{|c|}{ Elbow } \\
\hline & $\mathrm{Rt}$ & $\mathrm{Lt}$ & $\mathrm{Rt}$ & $\mathrm{Lt}$ \\
\hline Mean & 2.32 & 2.34 & 5.77 & 5.48 \\
\hline SD & 0.26 & 0.22 & 1.04 & 0.66 \\
\hline SEM & 0.093 & 0.081 & 0.368 & 0.23 \\
\hline$t$-test & & -0.16 & & 0.66 \\
\hline Prop. & & 0.436 & & 0.25 \\
\hline \multirow[t]{2}{*}{ Sig. } & & Non-sig. & & Non-sig. \\
\hline & & & $\begin{array}{l}\text { Rt wrist vs } \\
\text { Rt Elbow }\end{array}$ & $\begin{array}{c}\text { Lt Wrist vs } \\
\text { Lt elbow }\end{array}$ \\
\hline$t$-test & & & -9.08 & -12.59 \\
\hline Prop. & & & 0.0001 & 0.0001 \\
\hline Sig. & & & HS & HS \\
\hline $\begin{array}{l}\text { SD } \\
\text { SEM } \\
t \text {-value }\end{array}$ & $\begin{array}{l}\text { tandard } \\
\text { tandard } \\
\text { tudent's }\end{array}$ & $\begin{array}{l}\text { jiation. } \\
\text { or of Mean. } \\
\text { st value. }\end{array}$ & $\begin{array}{ll}p \text {-value } & : \mathrm{P} \\
\text { Sig. } & : \mathrm{S} \\
\mathrm{HS} & : \mathrm{H}\end{array}$ & $\begin{array}{l}\text { ability. } \\
\text { ficance. } \\
\text { Significance. }\end{array}$ \\
\hline
\end{tabular}

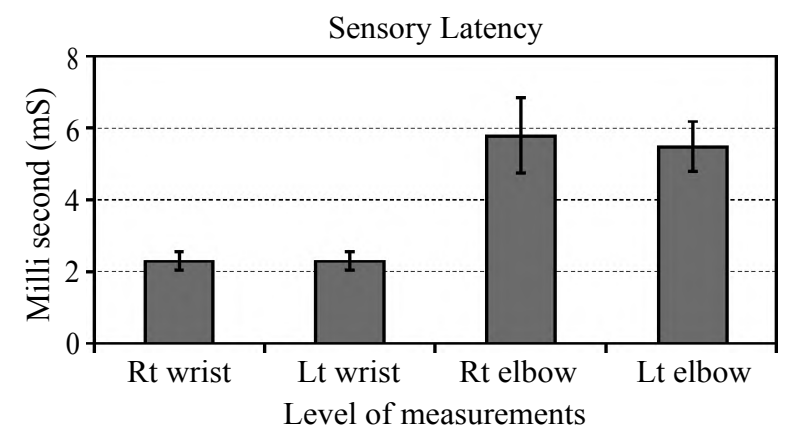

Fig. (4): Mean values of median nerve sensory latency of Group B.

\section{Discussion}

Using a computer mouse has a large effect on median nerve conduction velocity in computer users. The outcome measure used in this study was Electromyography (EMG) apparatus to measure the latency, amplitude and nerve conduction velocity of the median nerve of both hands to both groups.

In comparison between results of latencies, amplitudes and nerve conduction velocities of both hands in both groups there was a significant de- crease in the median nerve conduction velocity in both groups.

Based on evaluation of study design, sample sizes and response rates, case definitions and the exposure information, the studies by Andersen et al., Thomsen et al., and Atroshi et al., were the most likely to yield valid inferences. In two of the studies very intense computer work was represented (e.g. data entry, graphical work) $[13,14]$.

Andersen et al., [14] observed an association between mouse use and symptoms of CTS in the median nerve distribution area in both the cross sectional and in the follow-up analyses. The association was statistically significant for participants reporting more than $20 \mathrm{~h} / \mathrm{w}$ of mouse use with the risk almost tripled compared to the control group. A similar risk level was found in the study by Thomsen et al., [13].

Both studies had limitations. The study by Andersen et al. was performed during a time of intense debate on the potential hazards of mouse use in Denmark [14]. This may have influenced the results and thus explain why only associations with mouse use and not keyboard use was found.

Information bias caused by beliefs about certain associations may have very strong effects. This was shown in a study of indoor climate symptoms where reporting turned out to be dependent on the information given to the participants about the purpose of the study [15]

Another drawback of the study by Andersen et al., [14] was the lack of NCT in the CTS case definition. Also of concern was the observation that associations with the most specific CTS case definition were not as strong as associations with the less specific CTS case definition.

Thomsen et al., used a sensitive and specific CTS case definition (including NCT) and precise estimates of exposure with the use of questionnaires and direct measurements. The odds ratio of 1.86 was based on only 8 cases among the exposed and no cases among the control group. Furthermore, the interpretation was complicated by the fact that participants with data entry exposure were pooled with participants performing manual letter sorting [13] .

The study by Atroshi et al., showed quite convincingly the opposite of the expected, i.e. a negative association [16]. A limitation in this study could be the rather limited amount of keyboard work reported which would make it more difficult 
to show an effect. The exposure was self-reported and thus misclassification may have occurred. The possibility of reporting bias was limited because the participants were not aware of this special focus. The other cross-sectional study was difficult to interpret because of possible methodological bias, e.g. a much higher prevalence was found among men compared to women.

The case referent study by de Krom et al., was inconclusive. The number of exposed CTS cases in the study was very low and thus statistically unstable [17]. However, no pattern in the risk estimates was seen and all estimates were below unity. One of the strengths of the study was that the participants were blinded to the purpose of the study.

In summary, the results of the present study proved that using the computer mouse has a large effect on median nerve conduction velocity in computer users.

Further research should be conducted to study the effect of grasping different designs of computer mouse on median nerve conduction velocity in computer users, increase the sample size for each group in the future studies and using the study on different age groups.

\section{Conclusion:}

Within the limitation of this study, the following conclusions are warranted: using the computer mouse for a long time has a bad effect on median nerve conduction velocity in computer users.

\section{Limitation:}

Limitation of this study involved the small sample size.

\section{Acknowledgements:}

The authors express their sincere gratitude to all subjects who kindly participated in the study.

Conflicts of interest: None.

\section{References}

1- GERR F., MARCUS M., ENSOR C., KLEINBAUM D., COHEN S., EDWARDS A., GENTRY E., ORTIZ D.J. and MONTEILH C.: A prospective study of computer users: I. Study design and incidence of musculoskeletal symptoms and disorders. Am. J. Ind. Med., 41 (4): 22135, 2002.

2- JENSEN C., FINSEN L., SOGAARD K. and CHRISTENSEN H.: Musculoskeletal symptoms and duration of computer and mouse use. Int. J. Ind. Ergonom., 30: 265$75,2002$.
3- PILEGAARD M. and JENSEN B.R.: An 18-month followup study on vibrotactile sense, muscle strength and symptoms in computer users with and without symptoms. Int. Arch. Occup. Environ. Health, 78: 486-92, 2005.

4- TORNQVIST E.W., HAGBERG M., HAGMAN M., RISBERG E.H. and TOOMINGAS A.: The influence of working conditions and individual factors on the incidence of neck and upper limb symptoms among professional computer users. Int. Arch. Occup. Environ. Health, 82 (6): 689-702, 2009.

5- HAGBERG M.: ABC of work related disorders: Neck and arm disorders. Br. Med. J., 313 (7054): 419-22, 1996.

6- MING Z. and ZAPROUDINA N.: Computer use related upper limb musculoskeletal (ComRULM) disorders. Pathophysiology, 9 (3): 155-60, 2003.

7- CONLON C.F. and REMPEL D.M.: Upper extremity mononeuropathy among engineers. J. Occup. Environ. Med., 47 (12): 1276-84, 2005.

8- ELMAN L. and McCLUSKEY L.: Occupational and sport related traumatic neuropathy. Neurologist., 10 (2): 8296, 2004.

9- AL-HASHEM F.H. and KHALID M.E.: The effect of long-term use of computer mouse devices on median nerve entrapment. Neurosciences (Riyadh), 13 (2): 1315,2008 .

10- MURATA K., ARAKI S., OKAJIMA F. and SAITO Y.: Subclinical impairment in the median nerve across the carpal tunnel among female VDT operators. Int. Arch. Occup. Environ. Health, 68: 75-9, 1996.

11- WEISS N.D., GORDON L., BLOON T., SO Y. and REMPEL D.M.: Position of the wrist associated with the lowest carpal tunnel pressure: Implications for splint design. J. Bone Joint Surgery, 77A: 1695-9, 1995.

12- WERNER R., ARMSTRONG T.J., BIR C. and AYLARD M.K.: Intracarpal canal pressures: The role of finger, hand, wrist and forearm position. Clin. Biomechan., 12: 44-51, 1997.

13- THOMSEN J.F., HANSSON G.A., MIKKELSEN S. and LAURITZEN M.: Carpal tunnel syndrome in repetitive work: A follow-up study. Am. J. Ind. Med., 42: 344-53, doi: 10.1002/ajim. 10115, 2002.

14- ANDERSEN J.H., THOMSEN J.F., OVERGAARD E., LASSEN C.F., BRANDT L.P., VILSTRUP I., et al.: Computer use and carpal tunnel syndrome: A 1-year follow-up study. J.A.M.A., 289: 2963-9. doi: 10.1001/ jama.289.22.2963, 2006.

15- BRAUER C. and MIKKELSEN S.: The context of a study influences the reporting of symptoms. Int. Arch. Occup. Environ. Health, 76: 621-4. doi: 10.1007/s00420-0030463-4, 2003.

16-ATROSHI I., GUMMESSON C., ORNSTEIN E., JOHNSSON R. and RANSTAM J.: Carpal tunnel syndrome and keyboard use at work: A population-based study. Arthritis Rheum., 56: 3620-5. doi: 10.1002/art.22956, 2007.

17- De KROM M.C., KESTER A.D., KNIPSCHILD P.G. and SPAANS F.: Risk factors for carpal tunnel syndrome. Am. J. Epidemiol., 132: 1102-10, 1990. 




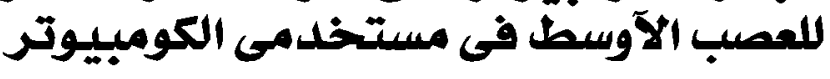

المقدمة:مستخدمى الكومبيوتر الذين يستخدمن الكومبيوتر لفترات طويلة يتآثر لديهم الجهاز العضلى الحركى والجهاز العصبى. الهدف: يهدف هذا البحث إلى دراسة تاتثير الإمساك بفآرة الكومبيوتر على متوسط سرعة التو صيل العصبى للعصب الآوسط فى مستخدى الكومبيوتر.

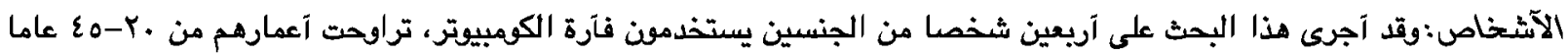
ويستخدمون الكومبيوتر كجزء آساسى فى عملهم وهذه الدراسة تمت بقسم العلاج الطبيعى بمستشفى الصعالصية الجديد ة المركزيى التابع لوزارة

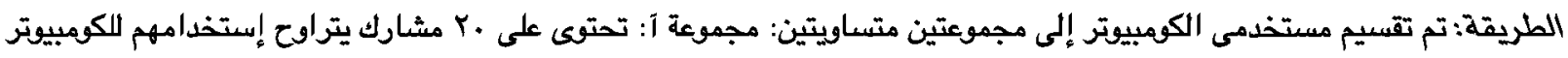

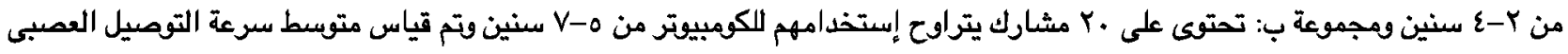
اللعصب الآوسط لكتا اليدين المجموعتين.

النتائج: كان هناك تآثير كبير لإستخدام الكمبيوتر لفترات طويلة على متوسط سرعة التوصيل العصبى للعصب الآوسط فى مستخدمى الكومبيوتر.

الخاتمة: إستخدام فآرة الكومبيوتر لفترات طويلة يؤثر سلبا على متوسط سرعة التوصيل العصبى اللعصب الأوسط فى مستخدمى الكومبيوتر. 